\title{
Tramas dramáticas: as redes teatrais brasileiras entre o sistema moderno e o sistema de indicadores
}

\section{Dramatic webs: Brazilian theatrical networks between the modern system and the system of indicators}

Manoel Silvestre Friques ${ }^{1}$ 


\section{Resumo}

O presente ensaio recupera a noção de "sistema teatral" - associada à figura de Décio de Almeida Prado com a finalidade de refletir a respeito da necessidade de um enfoque sistêmico do teatro brasileiro no âmbito do Capitalismo Cognitivo cadenciado por políticas recentes de austeridade. Para isso, contextualiza os esforços de Prado em relação a seus pares, discípulos e questionadores, passando em seguida a justapor o sistema moderno ao sistema contemporâneo de indicadores culturais. Compreendendo a insuficiência das análises econômicas para um diagnóstico adequado da produção teatral do país, o ensaio termina com a proposição de um enfoque sob o paradigma sociotécnico das redes teatrais.

Palavras-Chaves: Teatro brasileiro; sistemas complexos; redes sociotécnicas; indicadores culturais

\section{Abstract}

This essay recovers the notion of "theatrical system" coined by Decio de Almeida Prado in order to reflect on the need for a systemic approach of the Brazilian theater within the scope of Cognitive Capitalism cadenced by recent austerity public policies. To do so, it contextualizes Prado's efforts within a discursive field composed by his peers, disciples and questioners. Then, it juxtaposes the modern system with the contemporary system of cultural indicators. Verifying the insufficiency of economic analysis for an adequate diagnosis of Brazilian theatrical production, the text ends proposing an approach under the paradigm of sociotechnical theater networks.

Keywords: Brazilian theater; complex systems; sociotechnical networks; cultural indicators 
No campo cultural, os acontecimentos recentes no cenário político brasileiro - o risco de extinção do Ministério da Cultura contornado pela mobilização social policêntrica dos OcupaMinc; a descontinuidade de políticas culturais, com as esferas governamentais não honrando suas promessas registradas em editais, ação confrontada com as reações civis organizadas por artistas e produtores culturais; e também a interferência direta de figuras políticas nos processos decisórios de instituições culturais, gerando interditos mais ou menos explícitos de performances e exposições - nos forçam a pensar em modos de sistematização da produção teatral brasileira que se desviem de e/ou questionem o aparato estatal. O que se faz aqui é justamente isso: pretende-se oferecer possíveis caminhos que conduzam a uma abordagem sistemática do campo da criação teatral brasileira, compreendendo-se este enquanto passo fundamental para o diagnóstico setorial de nossa produção que não desconsidere, por sua vez, a capilaridade e a flexibilidade dos processos em proveito de indicadores agregados e desterritorializados. Para isso, o caminho reflexivo recupera os primeiros esforços de sistematização de nossa produção elaborados por Décio de Almeida Prado, com o objetivo de se pensar em uma articulação inédita entre o teatro e a tecnologia que não esteja unicamente circunscrita às conquistas estéticas das criações teatrais.

Quando pensamos a respeito das possíveis imbricações entre o teatro e a tecnologia, deparamo-nos esquematicamente com duas perspectivas antagônicas: de um lado, formula-se uma competição entre práticas culturais anciãs e novatas (a sobrevivência do teatro apesar das novas tecnologias); de outro, investiga-se certa adequação entre os termos por meio de estratégias de incorporação das novas tecnologias às práticas teatrais e vice-versa (a utilização de toda sorte de gadgets e dispositivos no acontecimento teatral, reconfigurando-o, ou a presença do teatro na world wide web) (Friques, 2011; Friques, 2014).

Apesar de válidas e férteis, as duas perspectivas esboçadas não esgotam tal relação, deixando em aberto uma discussão a respeito de algumas transformações estruturais catalisadas pelo acelerado processo de digitalização do mundo contemporâneo. Talvez a mais importante destas mudanças se refira aos sistemas informacionais que cadenciam a produção, a distribuição e o consumo atuais, organizando, modelando e monitorando os diversos fluxos contemporâneos (de dinheiro, de pessoas, de objetos, de serviços, de posts e likes etc.) por meio de bases de dados, softwares (seja de open, close e/ou big-data), aplicativos, dentre outros dispositivos. Estas plataformas digitais oferecem abordagens sistêmicas que, quando aplicadas ao teatro, exigem uma reconsideração de seus conceitos historiográficos fundamentais. Faz-se necessário então realizar uma aproximação entre as abordagens sistêmicas dos historiadores teatrais e aquelas mais recentes propostas pelas onipresentes tecnologias digitais.

O presente artigo justifica-se por isso, comprometendo-se por oferecer ao leitor respostas plausíveis à seguinte pergunta: quais são as transformações que a noção de "sistema teatral brasileiro" - desenvolvida no âmbito da crítica, da historiografia e da história do teatro brasileiro - deve empreender de modo a se adequar às abordagens sistêmicas mais recentes - associadas sobretudo aos sistemas de indicadores culturais no contexto da Engenharia de Produção Cultural, da Gestão Cultural e da Economia da Cultura? 


\section{Genealogias do sistema}

A ampla disseminação da noção de sistema baseia-se em uma aproximação entre as ciências naturais e as humanidades, denotando aí uma mudança epistemológica transversal. Prova disto é compartilhamento histórico deste conceito tanto por parte de críticos literários - como é o caso de Antônio Candido e seu "Formação da Literatura Brasileira", elaborado entre 1945 e 1951, e publicado em 1959 - quanto por parte de cientistas - caso do biólogo austríaco Ludwig von Bertalanffy, responsável pela formulação de uma "Teoria Geral dos Sistemas" na mesma época. Se tais exemplos são importantes, a linguística estrutural de Ferdinand de Saussure seria ainda mais determinante à consolidação do sistema enquanto framework de análise, sendo fundamental ao pensamento de autores como Maurice Merleau-Ponty e Claude Lévi-Strauss.

Para Saussure, a linguagem é um sistema de signos onde cada elemento não possui valor intrínseco, mas cujo sentido depreende-se das relações diferenciais que ele mantém com os demais, pois, "no tocante à linguagem, se é a relação lateral do signo com o signo que torna ambos significantes, o sentido só aparece na interseção e como que no intervalo das palavras" (Merleau-Ponty, 2013, p. 63). A significação advém não da soma dos sentidos oriundos dos elementos discretos, mas de uma "arquitetura de signos", na medida em que sua unidade é "unidade de coexistência, como a dos elementos de uma abóbada que se escoram mutuamente" (Merleau-Ponty, 2013, p. 60). Em Merleau-Ponty, as relações diacríticas pressupostas no sistema linguístico assumiriam papel preponderante em suas reflexões sobre a percepção e a expressão.

A linguagem adquire também uma centralidade no estruturalismo de Claude Lévi-Strauss, servindo de modelo a investigações que abarcam fenômenos sociais pautados pelo entrelaçamento de aspectos distintos, conforme se constata nesta passagem de Tristes Trópicos:

O conjunto dos costumes de um povo é sempre marcado por um estilo; eles formam sistemas. Estou convencido de que esses sistemas não existem em número ilimitado, e que as sociedades humanas, assim como os indivíduos - em seus jogos, seus sonhos ou seus delírios - jamais criam de modo absoluto, mas se limitam a escolher certas combinações num repertório ideal que seria possível reconstituir. (Lévi-Strauss, 1996, p. 167)

As esferas sociais são investigadas por Lévi-Strauss por meio da utilização de um termo operatório comum: a noção de estrutura. O estabelecimento de analogias entre arte, religião e sociedade o conduz a uma definição de uma estrutura comum que se manifesta em cada uma das dimensões, mas não se reduz inteiramente a nenhuma delas. Pois, a estrutura investigada por Lévi-Strauss não se limita aos elementos físicos e materiais. Tenha-se em mente que a estrutura é um modo de pensamento que busca transcender a oposição sensível-inteligível, entrelaçando categorias empíricas, ferramentas conceituais e noções abstratas. A busca de Lévi-Strauss é pelos imperativos mentais: daí seu interesse pelo signo, a meio caminho da percepção estética e do pensamento lógico. Daí ele afirmar que "o plano da aldeia bororo não exprime a verdadeira estrutura social, e sim um modelo presente na consciência" (Lévi-Strauss, 
2012, p. 420). Daí também seu interesse por outros campos do saber, em especial as teorias da comunicação - sendo este interesse crucial à presente discussão - que, no seu entender, teriam um efeito unificador ao entrelaçar a antropologia social, a ciência econômica e a linguística a partir das noções de comunicação e informação (Lévi-Strauss, 2012, p. 426).

Enquanto Merleau-Ponty e Lévi-Strauss, cada um a seu modo, apropriam-se do sistema linguístico em suas investigações respectivas aos princípios perceptivos e aos imperativos mentais, no Brasil, o sistema seria um conceito central ao pensamento crítico de alguns autores - em especial Antônio Candido e Décio de Almeida Prado em seu esforço de circunscrever o projeto moderno cultural brasileiro sob a sombra colonial dos transplantes de modelos culturais europeus.

\section{O Sistema Teatral Brasileiro}

É difícil negar que a proposição de uma abordagem holística fundada no conceito de sistema seja fruto dos estudos literários de Antônio Candido, adaptados paralelamente aos casos teatral e audiovisual por Décio de Almeida Prado e Paulo Emílio Sales Gomes, respectivamente. Conforme sintetiza João Roberto Faria (1998, p. 15-16),

É no romantismo que o teatro brasileiro se constitui como um "sistema" integrado por autores, atores, obras e público. Desse modo, à semelhança de seus companheiros de geração, Antônio Candido e Paulo Emílio Sales Gomes, que estudaram o processo formativo da literatura e do cinema em nosso país, Décio de Almeida Prado procurou fazer o mesmo com o teatro, investigando o primeiro momento - ou o que Antônio Candido chamaria de "momento decisivo" - em que houve entre nós as condições intelectuais e materiais que puderam proporcionar uma continuidade fecunda do trabalho cênico.

Antônio Candido define as etapas formativas do "sistema literário brasileiro", elaborando análises críticas que buscam circunscrever o valor e a função das obras literárias. Reconhecendo a importância das "ralas e esparsas" manifestações literárias brasileiras - dos autos e cantos do século XVI às Academias do século XVIII -, ele propõe, enquanto pressuposto basilar de seu estudo, um enquadramento metodológico fundado na noção de sistema, ou seja, uma interação dinâmica entre autor-obra-público permeada pela tradição. Sob tal perspectiva, a literatura "brasileira não nasce, é claro, mas se configura no decorrer do século XVIII, encorpando o processo formativo, que vinha antes e continuou depois" (Candido, 2000, p. 16). À semelhança do que notou em Raízes do Brasil, sua argumentação baseia-se na "velha dicotomia da reflexão latino-americana" (Candido, 2014, p. 13), cabendo à Metrópole os atributos de refinado, civilizado e culto, e à Colônia, de rude, primitivo e rudimentar. No cerne deste debate, encontra-se a distinção entre manifestação e sistema assim elaborada por ele:

Para compreender em que sentido é tomada a palavra formação, e porque se qualificam de decisivos os momentos estudados, convém principiar distinguindo manifestações literárias, de literatura propriamente dita, considerada aqui um sistema de obras ligadas por denominadores comuns, que permitem reconhecer as notas dominantes duma fase. Estes denominadores são, além das características 
internas (língua, temas, imagens), certos elementos de natureza social e psíquica, embora literariamente organizados, que se manifestam historicamente e fazem da literatura aspecto orgânico da civilização. Entre eles se distinguem: a existência de um conjunto de produtores literários, mais ou menos conscientes do seu papel; um conjunto de receptores, formando os diferentes tipos de público, sem os quais a obra não vive; um mecanismo transmissor, (de modo geral, uma linguagem, traduzida em estilos), que liga uns a outros. O conjunto dos três elementos dá lugar a um tipo de comunicação inter-humana, a literatura, que aparece sob este ângulo como sistema simbólico, por meio do qual as veleidades mais profundas do indivíduo se transformam em elementos de contato entre os homens, e de interpretação das diferentes esferas da realidade. (Candido, 2000, p. 23)

Observa-se aí as premissas deste sistema, definido enquanto um ato de comunicação e, portanto, estruturado a partir de seus elementos constituintes emissor-obra-receptor, sendo a tradição também um meio, ou denominador comum, do processo comunicativo. O sistema não procura mapear irrestritamente todo o conjunto de processos comunicativos produzidos em um dado período histórico, mas tão somente aqueles que participam da constituição de uma consciência nacional conforme o juízo crítico intimamente relacionado ao projeto formativo de Antônio Candido. Nota-se, a partir da análise empreendida por Luís Costa Lima, que o sistema literário de Candido pressupõe um funcionamento orgânico e coerente, estreitamente vinculado à formação e à afirmação de uma consciência nacional. ${ }^{2}$

Para Costa Lima, a ênfase de Antônio Candido na organicidade e na harmonia do sistema é devedora da influência da antropologia social britânica, em especial, de Alfred R. Radcliffe-Brown (1881-1955). A importância de Radcliffe-Brown ao pensamento de Candido é tal que o crítico brasileiro de formação sociológica "seria eventualmente o autor da mais importante obra de inspiração estrutural-funcionalista jamais escrita na língua portuguesa, Os parceiros do Rio Bonito" (Thomaz \& Pina Cabral, 2011, p. 187). Considerando esta relação entre Candido e Radcliffe-Brown, constata-se a distância determinante que a abordagem sistêmica do crítico brasileiro assume em relação ao pensamento estruturalista de Lévi-Strauss. ${ }^{3}$

Justamente por isso, não é difícil observar em Antônio Candido o paralelismo entre a história de independência e de modernização do Brasil e o desenvolvimento de seus sistemas culturais, ambos moldados à semelhança do ciclo de vida do ser humano e de sua tomada de consciência (não à toa, surgem metáforas como aquela em que o indianismo é sintetizado enquanto fenômeno de adolescência nacionalista

\footnotetext{
2 A tomada de consciência, vinculada ao critério de organicidade, é também bastante importante para Paulo Emílio Sales Gomes quando elabora a sua formação do cinema brasileiro, batizada de "Panorama do Cinema Brasileiro: 1896/1966". Ao comentar o advento das revistas Selecta, Paratodos e Cinearte - que marca a terceira fase do cinema nacional, de 1923 a 1933 -, Gomes afirma que "é desse momento em diante que se manifesta uma verdadeira tomada de consciência cinematográfica [...]" (Gomes, 1996, p. 51).

3 Em "A noção de estrutura em etnologia", Lévi-Strauss confere um lugar de destaque ao "programa lúcido" de Radcliffe-Brown, sem deixar, contudo, de estabelecer um contraponto ao afirmar que "ele tem uma concepção das estruturas sociais diferente da que é proposta neste trabalho", visto que fundada em uma analogia íntima entre estrutura orgânica e estrutura social. "Longe de elevar o nível dos estudos de parentesco à teoria da comunicação, como propus", destaca Lévi-Strauss, "Radcliffe-Brown o reduz ao da morfologia e da fisiologia descritiva". $O$ fato de as distinções entre modelo e realidade, bem como entre estrutura e relações, serem alheias ao antropólogo britânico explicam a sua "hostilidade em relação à noção de cultura [...] e sua indiferença para com os ensinamentos da linguística" (Lévi-Strauss, 2012, p. 436-8). De fato, em um ensaio como "Estudos dos Sistemas de Parentesco", nota-se o esforço de Radcliffe-Brown em definir o sistema enquanto "unidade complexa, um todo organizado" como aquele dos seus conterrâneos ingleses que "satisfaz as necessidades de uma vida social organizada e é otimamente autoconsciente" (Radcliffe-Brown, 1973, p. 71 e 108).
} 
ou a obra de Machado de Assis, símbolo da maioridade da literatura brasileira). ${ }^{4} \mathrm{De}$ fato, a noção de sistema está intimamente entrelaçada à questão da formação da literatura brasileira, não sendo possível separá-las. Eis porque o sistema de Candido está imbuído do projeto formativo do crítico, por meio do qual o olhar do estudioso elege os momentos decisivos para a constituição do sistema literário brasileiro.

A preocupação com um projeto formativo não é um atributo isolado de Antônio Candido, mas algo que pode ser observado transversalmente nas trajetórias de muitos intelectuais modernos latino-americanos. No contexto brasileiro, Candido integra, ao lado de nomes como Paulo Emílio Sales Gomes, Sérgio Buarque de Holanda e Gilberto Freyre, uma geração de intérpretes do Brasil que, tendo recebido pela primeira vez por aqui uma formação universitária sistemática e não mais autodidata, ${ }^{5}$ foi responsável por estabelecer parâmetros fundadores aos debates sobre os processos socioculturais de nosso país. Neste grupo também se encontra o crítico teatral Décio de Almeida Prado, responsável pela adequação do sistema de Candido ao contexto cênico moderno.

Pode-se dizer que Prado tratou de assumir a lacuna deixada conscientemente por Candido, ao excluir, conforme o mesmo relata, a literatura dramática de seu sistema (Candido, 2000, p. 12). A permanência do sistema é rapidamente constatada, por exemplo, nos momentos iniciais de "O Teatro Jesuítico", onde se lê que

O teatro chegou ao Brasil tão cedo ou tão tarde quanto se desejar. Se por teatro entendermos espetáculos amadores isolados, de fins religiosos ou comemorativos, o seu aparecimento coincide com a formação da própria nacionalidade, tendo surgido com a catequese das tribos indígenas feita pelos missionários da recém-fundada Companhia de Jesus. Se, no entanto, para conferir ao conceito a sua plena expressão, exigirmos que haja uma certa continuidade de palco, com escritores, atores e público relativamente estáveis, então o teatro só terá nascido alguns anos após a Independência, na terceira década do século XIX. (Prado, 1993, p. 15)

Observa-se neste trecho alguns parâmetros que serão amplamente utilizados por Prado nos estudos onde procura delinear as coordenadas históricas e culturais da formação do teatro brasileiro. Significativamente, há aqui em operação os termos amador e isolado, que, justapostos, remetem diretamente a uma leitura, um tanto problemática, das sociedades indígenas pré-coloniais. De fato, e nem Prado nem Candido parecem negar isso, o teatro (e/ou a literatura) são compreendidos enquanto formas culturais europeias cuja condição de existência e de sobrevivência está intimamente vinculada à colonização. Teatro e literatura são, pois, instrumentos urbanos civilizatórios.

A transposição do sistema literário aos casos teatral e audiovisual não é realizada sem problemas. Gomes, por exemplo, parece conferir validade ao seu sistema por meio da já

\footnotetext{
4 Não se está querendo dizer que Candido endossa uma leitura das obras através dos fatores sociológicos e biográficos extraliterários que lhe condicionam. Deve-se ter em mente o esclarecimento que o autor fornece no prefácio à segunda edição de sua "Formação da Literatura Brasileira", quando afirma que "o presente livro é um estudo de obras; a sua validade deve ser encarada em função do que traz ou deixa de trazer a este respeito. As ideias teóricas que encerra só aparecem como enquadramento para estudar as produções" (Candido, 2000, p. 15). Assim, por maior que seja sua inspiração sociológica, o sistema é elaborado para servir às leituras críticas do seu autor, a partir de uma relação dialética entre texto e contexto, de modo que a dimensão social surja como próprio fator de construção artística através de operações de "transfiguração". (Sussekind, 2014, p. 54)

5 Quem nos informa sobre isso é Roberto Schwarz, em verbete sobre o autor publicado no blog da editora Boitempo: https://blogdaboitempo.com.br/2017/05/12/ antonio-candido-por-roberto-schwarzl. Acesso em: 11 set.2017.
} 
referida tomada de consciência, mas sobretudo da "solidariedade de interesses entre os fabricantes de filmes nacionais e o comércio local de cinematografia" (Gomes, 1996, p. 36) que ele constata em períodos específicos (em especial, em 1908-11 e nas chanchadas da Atlântida). Note-se que as condições materiais se distinguem das condições intelectuais: a confluência de interesses industriais e comerciais se dá em momentos outros que a tomada de consciência que representou o advento das revistas sobre cinema. Prado (1993, p. 90) parece seguir os passos de Candido ao valorizar o estabelecimento da família Real portuguesa em 1808 enquanto catalisador de um "movimento ininterrupto de criação dos mais diversos instrumentos culturais, inclusive as escolas de ensino superior" e também "bibliotecas, associações científicas e literárias, tipografias, jornais, revistas, teatros" (Candido, 2004, p. 48).

O descompasso entre as condições materiais e aquelas intelectuais norteia também o sistema teatral de Décio de Almeida Prado. A título de exemplo, basta que se diga que o autor, ao investigar a atuação daquele que é considerado o primeiro crítico teatral brasileiro - Justiniano José da Rocha - afirme que "o teatro nacional passara a existir e Justiniano não percebera", devido ao fato deste ter deixado

[...] passar em branco os dois acontecimentos julgados pela posteridade como fundamentais - no sentido de inaugurais - do período. Ou seja, a encenação da tragédia Antônio José e a Inquisição, de Gonçalves de Magalhães, e da comédia O Juiz de Paz da Roça, de Martins Pena, respectivamente em março e outubro de 1838. (Prado, 1993, p. 138-9)

Ambas as encenações foram protagonizadas por João Caetano dos Santos, havendo aí um circuito, só considerado posteriormente pela lente de Prado, inteiramente brasileiro. Porém, não seriam estes espetáculos as obras-primas do período, mas um texto de Gonçalves Dias, Leonor de Mendonça, que, nos lembra João Roberto Faria, "foi recusada por João Caetano" (Faria, 1998, p. 27). Faria também pontua que apesar de o teatro ter sido um dos principais veículos dos dramaturgos românticos brasileiros, as montagens do período privilegiavam as traduções europeias. Ora, seria este o mesmíssimo problema - bastante atual - do cinema brasileiro diagnosticado por Gomes, ao afirmar que "os interesses do comércio cinematográfico nacional giram em torno do cinema importado, prosseguindo o mercado atual saturado pelo produto estrangeiro" (Gomes, 1996, p. 83).

Estes exemplos, além de apontarem para o descompasso entre as condições materiais e intelectuais, estabelecem uma diferença histórica entre a recepção crítica das obras, em especial quando se tem em mente que as formações aqui consideradas (da literatura, do teatro, do cinema) são narradas por críticos-historiadores, isto é, por narradores que não escondem a parcialidade de seus exercícios judicativos. Esta questão é determinante, pois a perspectiva moderna de Décio de Almeida Prado o faz, conforme pontua Berilo Nosella (2010), subestimar a importância da comédia para a Formação do Teatro Brasileiro. Porém, considerando a importância secundária, em seus contextos imediatos de recepção, dos textos dramáticos cotejados por Prado, não haveria aqui (em favor de um suposto teatro moderno e sério, é verdade) uma estratégia bastante significativa de des-repressão? 
Seja como for, é aconselhável considerar em conjunto os estudos de Décio de Almeida Prado em seu esforço, à semelhança de seus pares, por narrar criticamente a formação do teatro brasileiro. Assim, ao lado de sua declarada perspectiva textocêntrica - notadamente em O Drama Romântico Brasileiro - merecem destaque pesquisas onde a trajetória de personalidades pontuais representa o estabelecimento de funções sistêmicas, seja João Caetano enquanto empresário e ator, Justiniano José da Rocha enquanto crítico, Gonçalves de Magalhães enquanto dramaturgo etc. Com o passar do tempo, o empenho sistematizador de Prado ganha herdeiros, bastardos, pares e revisores. Se Nosella, em estreita conexão com Betti Rabetti, apresenta uma revisão do sistema teatral de Prado sob o ponto de vista da comicidade de gêneros considerados menores como a comédia de costumes, a revista de ano, a burleta etc., tanto Sábato Magaldi quanto Barbara Heliodora deixam ressoar em seus estudos o esquema histórico do autor, conforme se constata respectivamente em Panorama do Teatro Brasileiro e Caminhos do Teatro Ocidental. Apesar de nutrir algumas ressalvas historiográficas em relação aos estudos, dentre outros historiadores, de Décio de Almeida Prado, Tania Brandão também reafirma a presença de um sistema teatral brasileiro a partir dos mesmos marcos, com certos deslocamentos de ênfase do feito dramatúrgico para o acontecimento cênico pautado em uma espécie de, para utilizar os termos de Paulo Emílio Sales Gomes, "solidariedade de interesses" entre palco e plateia:

\footnotetext{
Os princípios ordenadores do sistema teatral foram, desde os primeiros tempos, muito mais o gosto médio do público, o senso comum, o favor da multidão e o histrionismo dos atores identificados com esta pulsão da plateia, do que quaisquer plataformas estético-conceituais ou projetos culturais conscientes [...] A questão central do sistema teatral não estava na dramaturgia, nunca esteve; e esta é uma peculiaridade nacional. (Brandão, 2001, p. 35)
}

Neste sistema, compreendido sob a hipótese de existência de um mercado teatral, sobressai a hegemonia teatral do eixo RJ-SP, a "Meca procurada por todos os que anseiam obter projeção nacional" (Brandão, 2001, p. 204). Em outra ocasião, a historiadora pontua que "o século $[X X]$ não viu nascer um mercado teatral nacional no rigor dos termos. Assim, o sistema teatral brasileiro foi muito mais o teatro profissional praticado no Rio e em São Paulo" (Brandão, 2001b, p. 301). À hegemonia regional sobrepõe-se a hegemonia estelar. Ecoando o "personalismo, de que provêm a frouxidão das instituições e a falta de coesão social" (Candido, 2014, p. 15) descritos por Sérgio Buarque de Holanda, a história do teatro seria uma história das estrelas, do "divismo tropical", compreendendo-se "estrela" enquanto imagem social construída pelo artista - personalidade empreendedora - e não apenas sua trajetória individual.

Sob uma perspectiva talvez diametralmente oposta à de Brandão, encontram-se as pesquisas de Walter Lima Torres Neto e André Carreira. Com um viés mais sociológico, buscando compreender as relações possíveis entre teatro e sociedade, Torres Neto articula três noções holísticas, a saber: cultura teatral, sistema organizacional e mercado teatral. Estas três dimensões estão intimamente associadas:

[...] cultura teatral poderia englobar um conjunto de condicionamentos e procedimentos, de regras, de técnicas artísticas (trabalho intelectual e esforço criativo) e estratégias comerciais, elementos que estão em permanente atrito com tradições 
e inovações estéticas e que, juntos, objetivam a concepção, execução e posterior fruição de uma obra cênica, seja ela ficcional, representacional ou não. Um sistema teatral, consequentemente, refletiria as ações e reações relativas aos modos de operar, bem como revelaria as propriedades dessa cultura teatral, de onde emerge a dinâmica necessária que subsidia esse mesmo sistema organizacional. Assim, debruçando-se sobre as particularidades de uma determinada cultura teatral composta por seus agentes, valores, temas, instituições, procedimentos criativos, processos de produção e comercialização do trabalho criativo, seria possível identificar como se configura um determinado sistema teatral. (Torres Neto, 2015, p. 28-29)

O sistema, por sua vez, a depender do grau de sua sistematicidade, possibilitaria a emergência de um mercado teatral. Seria, pois, o grau de articulação destas três esferas distintas que permitiria ao analista considerar as diversidades regionais: locais com cultura teatral, mas sem sistemas e mercados, por exemplo. Já Carreira busca compreender a atividade teatral brasileira coletando e cotejando informações sobre os teatros de grupo, tendo entrevistado mais de sessenta deles de diferentes regiões brasileiras. Dentre as suas conclusões, destaca-se a seguinte:

Observando a complexidade dos diferentes ambientes teatrais do país, onde convivem realidades muito díspares é possível dizer que não se pode identificar de fato um 'sistema teatral brasileiro unificado'. Se o fazemos não é mais que como instrumento didático. Pensamos um 'teatro brasileiro', mas ele é apenas a somatória de uma enorme quantidade de modos de produção e de uma diversidade na qual convivem modos de produção muito distintos. (Carreira, 2008, p. 4)

De fato, conforme argumenta Carreira, deve-se afirmar a existência de um sistema teatral unificado apenas didaticamente, visto que este mesmo sistema não é organicamente coerente. Daí o autor substituir sistema por soma. Contudo, deve-se ter cautela nesta substituição. Com certa prudência, o uso do conceito de sistema pode ser de grande valia, caso se opere o divórcio entre esta noção e as ideias de coerência e organicidade. Em outras palavras, é preciso afastar-se da abordagem de Radcliffe-Brown - fundamental à matriz do pensamento sobre o sistema literário em Antônio Candido - e aproximar-se mais daquela de Lévi-Strauss, a partir das lições retiradas da linguística. Só assim o sistema será abordado a partir das relações diferenciais que os elementos constituintes mantêm entre si, lembrando-se ainda que estes elementos não detêm todos a mesma importância. Assim, o sistema brasileiro não é aquele do "divismo tropical" ou do "teatro moderno", mas um único sistema constituído pelas relações de proximidade e distanciamento, de atrações e repulsas, de embates e afinidades, entre um certo teatro vanguardista e outro mais comercial, entre o desejo de um teatro brasileiro e a realidade do mesmo. É este sistema diferencial e não coeso que tornam problemáticas

[...] as tentativas de estabelecer uma linha evolutiva do desenvolvimento do teatro brasileiro em direção à modernidade, pois [...] não é possível identificar uma matriz única para a chegada e o estabelecimento de ideias modernizadoras em nossos palcos, como se observa em inúmeras tentativas referentes à História do Teatro Brasileiro. (Guinsburg \& Patriota, 2012, p. 106-7) 
É também este sistema que será questionado mais recentemente com o advento de uma "estrutura de mercado" transversal a ambos - qual seja, as leis de incentivo - que reúne os aparentes polos dicotômicos através dos patrocínios (Friques, 2016).

A estas reconsiderações da noção de sistema, agregam-se outras. Tenha-se em mente os questionamentos referentes ao pressuposto comunicativo que circunscreve o modelo linear autor-obra-público, conforme sintetiza Stuart Hall ao afirmar que:

\footnotetext{
Tradicionalmente, a pesquisa em comunicação em massa tem concebido o processo comunicativo em termos de um circuito. Esse modelo tem sido criticado pela sua linearidade - emissor/mensagem/receptor; por sua concentração no nível da troca de mensagens; e pela ausência de uma concepção estruturada dos diferentes momentos enquanto complexa estrutura de relações. Mas é também (e útil) pensar esse processo de articulação de momentos distintos, mas interligados - produção, circulação, distribuição/consumo, reprodução. Isto seria pensar o processo como uma 'complexa estrutura em dominância', sustentada através da articulação de práticas conectadas, em que cada qual, no entanto, mantém sua distinção e tem sua modalidade específica, suas próprias formas e condições de existência. (Hall, 2013, p. 428)
}

No trecho acima, percebe-se o esforço de Hall por desnudar a aparente simplicidade do circuito comunicativo. Em primeiro lugar, tem-se a questão da suposta linearidade comunicacional, partindo-se, como era de se esperar, do emissor. Como esclarece Hall - para o caso televisivo, mas também adequado a outras situações comunicacionais - a audiência não é apenas o receptor, mas também a fonte da mensagem, sendo um momento deste processo produtivo. Ademais, produção e recepção não compartilham necessariamente o mesmo contexto histórico, podendo resultar daí uma série de incompreensões e dissensos. Quanto à produção, Hall expande a autoria da mensagem comunicativa apontando para a importância, para a sua construção, das estruturas institucionais, das práticas e redes de produção, de suas relações organizadas e infraestruturas técnicas. De modo mais significativo, o autor nos lembra que os "códigos de codificação e decodificação podem não ser perfeitamente simétricos", fazendo surgir desta falta de equivalência entre os lados da troca comunicativa as "distorções" ou "mal-entendidos" (Hall, 2013, p. 433).

Não é difícil concluir que as proposições de Hall, ao desnudarem a complexidade do sistema comunicativo, são justamente por isso mais adequadas para se pensar a respeito de um sistema teatral. O descompasso entre condições materiais e intelectuais; as diferentes reações de uma audiência popular e outra especializada; as disjunções entre idealizações e produções, entre produções e distribuições; as relações diferenciais entre os elementos constituintes; os distintos horizontes, espaciais e temporais, de agentes de um mesmo sistema, cadeia ou rede etc.: todos estes fatores apontam para uma complexidade estruturante de nosso sistema não contemplada, contudo, por uma abordagem linear deste sistema vinculada ao telos da modernidade.

Ao lado destas constatações, tem-se um outro fenômeno decisivo para tornar ainda mais complexa a discussão sobre os nossos sistemas teatrais. Trata-se do processo de digitalização do mundo contemporâneo, sobre o qual Vilém Flusser (2007), com certo olhar prognóstico, conceituou o "mundo codificado", onde a humanidade é programada por imagens técnicas, isto é, textos científicos aplicados. Quer ele sublinhar a centralidade, em todas as dimensões humanas, dos códigos eletrônicos 
onde todas as especificidades substanciais antigamente específicas a cada medium são niveladas em sistemas binários. Não há quem negue (e se aproveite e desconfie de) a onipresença das novas tecnologias de comunicação e informação: mesmo sem saber, produzimos, a todo momento, rastros tecnológicos que podem inclusive nos denunciar (lembre-se do embate entre Aaron Swartz e a central de periódicos científicos JSTOR). De fato, o prognóstico de Flusser aponta para uma mudança paradigmática no seio do pensamento econômico e que atende por nomes como "Capitalismo Cognitivo" e "Sociedade em Rede". É neste contexto onde são formuladas novas abordagens sistêmicas para as criações artístico-culturais, sendo esta discussão que agora devemos encarar.

\section{O sistema teatral entre as informações e as redes}

Era da Informação: tal é a expressão que o sociólogo espanhol Manuel Castells cunhou para diagnosticar, a partir da década de 60 do século $\mathrm{XX}$, uma complexa transformação estrutural das sociedades contemporâneas capitaneada por três fatores processuais: a revolução da tecnologia da informação6; a crise econômica do capitalismo e do estatismo; e o apogeu de movimentos sociais e culturais. Este novo mundo que passou a tomar forma nas últimas décadas é constituído, por sua vez, por uma nova estrutura social dominante - a sociedade em rede -, por uma nova economia - a economia informacional/global - e por uma nova cultura - cultura da virtualidade real (Castells, 2012).

No âmbito do Capitalismo Cognitivo fundado em intenso informacionalismo, o pensamento a respeito de um sistema teatral brasileiro se depara com instigantes desafios que podemos esboçar esquematicamente em duas frentes complementares: a da informação e a das redes. De um lado, surge a necessidade de um mapeamento agregado das atividades teatrais tendo em vista sua visibilidade naquilo que se conhece atualmente como o Sistema de Indicadores Culturais. Aqui, importa menos justificar mercantilmente o teatro brasileiro do que desenvolver um meio eficaz para a formulação de políticas públicas adequadas ao setor. Complementarmente, as redes de tecnologias digitais oferecem um modelo de organização que valorize, por assim dizer, as diversas relações e transações multidimensionais e heterogêneas que caracterizam tradicionalmente a produção teatral brasileira. Em outras palavras, as redes digitais lançam um novo olhar para as redes teatrais, que, por sua vez, deixam de estar à sombra de modelos industriais. Detalhemos, pois, os desafios do sistema teatral frente à emergência dos Sistemas de Indicadores, de um lado, e das Redes Territoriais, de outro.

\section{Indicadores Culturais e a Cultura dos Indicadores}

É quase impossível não perceber a onipresença dos indicadores em diversas dimensões de nossa vida. Seja nas distintas modalidades de esportes diários, no cuidado com 
a saúde, no uso do tempo (do celular, no trabalho ou com as crianças), em convites para festas e comemorações, em likes de depoimentos e declarações, em relatórios de acessos e downloads de vídeos ou artigos científicos, os indicadores se fazem onipresentes, nos auxiliando no monitoramento e no controle de nossas atividades de trabalho e lazer. As expressões culturais não fogem a esta Cultura dos Indicadores, como apontam os sistemas de indicadores culturais desenvolvidos nas últimas décadas em diversos países e também no Brasil.

Em 2004, o Instituto Brasileiro de Geografia e Estatística (IBGE) - coordenador do Sistema Estatístico Nacional - firmou um acordo de cooperação técnica com o Ministério da Cultura (MinC) com o propósito louvável de criar uma base de dados perene sobre as atividades econômicas associadas às produções culturais. $A$ tal base, ambas as instituições denominaram Sistema, com os três estudos publicados desde então batizados também de "sistemas", sendo "o sistema, sem as aspas", esclarecem Cristina Lins e Antônio Alkmin (2008, p. 60), "o projeto como um todo, um sistema integrado". A diferença delineada aqui entre "sistema" e sistema deve ser compreendida enquanto um esforço de sistematização das informações já existentes no primeiro caso e a construção de um Sistema de Indicadores Culturais no segundo caso, simbolizado pela ainda inédita Conta Satélite da Cultura.

Tais esforços endossam uma iniciativa política que deve ser compreendida no esforço federal de "recompor e ampliar a institucionalidade da área da cultura, que havia sido perdida nas décadas anteriores" (Calabre, 2017, p. 12) por meio da "organização, sistematização, produção de indicadores e análise de informações setoriais, nacionais e regionais, relacionadas ao setor cultural, a partir dos dados das pesquisas produzidas pelo Instituto" (Lins, 2008, p. 1). De modo mais amplo, o Brasil alinhava-se à tendência internacional de valorização da cultura enquanto fator fundamental de desenvolvimento socioeconômico, seguindo, no mesmo compasso que seus companheiros latino-americanos, ${ }^{7}$ as iniciativas já consolidadas de países como a França e os Estados Unidos.

Lins observa que a análise econômica da cultura se baseia em uma premissa conceitual aparentemente simples: a medição de bens ofertados e consumidos. Contudo,

[...] mesmo partindo de um princípio conceitual e metodológico simples (estudo da oferta e demanda de produtos associados à cultura), houve enorme dificuldade para mensurar a importância econômica da cultura no Brasil, em virtude da insuficiência de dados estatísticos sobre as atividades de produção de bens culturais no País. (Lins, 2007, p. 2-3)

\footnotetext{
7 Pode-se dizer que os Sistemas de Indicadores figuram entre as preocupações dos países ibero-americanos desde o início da século XXI fundamentalmente devido ao estímulo de instituições internacionais, conforme se constata nas agendas, a partir de 2002, de organismos multilaterais como Organização de Estados Americanos (OEA), a Organização dos Estados Ibero-americanos (OEI) , o Banco Interamericano de Desenvolvimento (BID) e a Organização do Convênio Andres Bello (CAB). O Mercosul Cultural, a despeito de certo descaso da entidade em relação aos assuntos culturais, é um importante mecanismo de Diplomacia Cultural fundamental à consolidação do "soft power" deste bloco. Cristina Lins destaca "que desde que se conformou o MERCOSUL Cultural, vários países da região avançaram na construção das Contas Satélite de Cultura, como é o caso da Colômbia, que consolidou o Manual metodológico para a Conta Satélite de Cultura na América Latina, em 2009, Chile, Uruguai com manual metodológico, Costa Rica, Argentina e Equador. Outros países, como Brasil, Peru, Bolívia e países da América Central estão trabalhando na sua elaboração" (LINS, 2015, p. 20-1). Nos países onde a Conta Satélite da Cultura - em especial, Bolívia, Equador, Paraguai, Peru, Panamá e República Dominicana - ainda não é uma realidade, "a principal limitante para sua medição é a falta de fontes de informação primárias e sistemas de organização, processamento e estandardização dos dados" (Rey, 2015, p. 182).
} 
Para se aferir a dimensão econômica da cultura, leva-se em consideração variáveis bastante disseminadas como emprego, renda, receitas e geração de valor adicionado. Para isso, o "sistema" partiu das informações disponíveis em outras bases estatísticas para elaborar os indicadores culturais. Em conjunto, o Sistema de Indicadores Culturais buscou determinar as principais características da oferta e da demanda dos bens e serviços culturais, considerando os gastos (das famílias e do governo, nos três níveis) e também o perfil socioeconômico do trabalhador do setor cultural.

Os primeiros relatórios buscaram compreender as informações já disponíveis em outras pesquisas, de modo a identificar as lacunas para o aprimoramento de uma base perene e densa de indicadores relativos à produção cultural brasileira. $O$ horizonte aqui é a construção de uma Conta Satélite da Cultura cujo objetivo principal será o de oferecer dados relativos ao, digamos, PIB Cultural. Nas palavras de Lins (2015, p. 17):

A medição econômica do setor cultural, mediante a criação de uma conta satélite de cultura, é um tema pioneiro de estudo nos países, que se esforçam na sistematização de informações extraídas das contas nacionais sobre as atividades econômicas relacionadas aos bens e serviços de cultura.

Tanto para a Conta Satélite da Cultura quanto para os "sistemas" publicados, a Classificação Nacional de Atividades Econômicas (CNAE) é a grande referência no que diz respeito a produção formal brasileira, sendo esta respaldada por padrões internacionais. De acordo com Lins, "essa nomenclatura é uma linguagem estatística que garante a comparabilidade internacional entre todos os institutos de pesquisa" (Lins, 2015, p. 8). A partir desta lista desagregada, circunscreve-se ah hoc o campo cultural selecionando-se as atividades econômicas - independente de sua natureza industrial, comercial ou de serviço - julgadas culturais, em especial aquelas associadas às indústrias culturais e demais produções tradicionais (livro, rádio, audiovisual, música, artes cênicas, espetáculos, bibliotecas, arquivos, museus e patrimônio). No caso brasileiro, houve a exclusão de atividades ligadas ao turismo, ao esporte, ao meio-ambiente e à religião. Às atividades diretas, inclui-se aquelas indiretas que contribuem para a oferta dos bens e serviços culturais. Daí, resulta o conjunto de atividades econômicas que circunscrevem o campo da oferta e da demanda culturais.

Até o momento, foram publicadas três versões do "Sistema de Informações e Indicadores Culturais". Nos dois primeiros (2006 e 2008), foi utilizada a CNAE 1.0. Em 2007, houve a revisão da CNAE 1.0 para a CNAE 2.0, com mudanças significativas nas categorias classificatórias e nos níveis hierárquicos, saltando-se para 673 a quantidade total de classes, com um aumento para 74 referentes àquelas (direta ou indiretamente) culturais. De modo mais explícito, introduz-se duas novas seções, dentre as quais uma explicitamente vinculada à produção cultural visando maior detalhamento: a "Seção R - Arte, Cultura, Esporte e Recreação".

No que concerne aos "sistemas" do IBGE, nota-se algumas características recorrentes, tais como a concentração da oferta cultural no setor de serviços (tanto no número de empresas quanto de pessoal ocupado) e os gastos públicos, considerando as três esferas de governo, somarem menos de 1\%. Deixando a análise de tais relatórios sob a perspectiva teatral para uma ocasião mais propícia, considere-se unicamente a reformulação de um sistema teatral sob a perspectiva dos informacio- 
nalismo que funda o Capitalismo Cognitivo. Neste contexto, nota-se uma profunda mudança no que se entende justamente por "sistema teatral".

Este novo sistema busca oferecer um diagnóstico da realidade da cultura compreendida enquanto setor econômico, tendo em vista o monitoramento, a avaliação e a formulação de políticas públicas adequadas (seja para geração de emprego e renda, seja na distribuição dos meios de produção). Se o enfoque é fundamentalmente econômico, deve-se, contudo, considerar tais esforços sistematizantes menos enquanto maneiras de legitimar mercantilmente a produção artística do que favorecer a formulação adequada de gestões culturais. Sendo assim, o sistema atual não é, como outrora, pautado pelo olhar crítico de um único pesquisador conforme o qual algumas atividades seriam valorizadas em detrimento de outras tendo em vista um processo de formação cultural. Ocorre, portanto, uma transformação na própria figura do crítico-historiador, que deixa de assumir a função de designer do sistema, portando-se apenas como mais um agente em seu interior.

Contudo, mesmo que não haja uma perspectiva crítica personalizada que desconsidere algumas atividades em proveito de outras, não se pode dizer que tenha cessado a invisibilidade de etapas, ações, relações e agentes de nosso sistema teatral. É olhando para os novos sistemas estatísticos, fundamentalmente quantitativos, que nos deparamos com a quase invisibilidade do teatro em termos de indicadores culturais.

\section{Sistemas teatrais complexos: cadeias ou redes?}

Os sistemas de indicadores culturais desenvolvidos no Brasil a partir da primeira década do século XXI buscam oferecer um diagnóstico da dimensão econômica das atividades artístico-culturais por meio de estudos de oferta e demanda de seus bens e serviços. $O$ enfoque estritamente econômico esbarra em diversos obstáculos, sendo talvez o maior deles a questão da informalidade das atividades teatrais. Quanto a isso, é bastante significativo que em seu estudo sobre a cadeia produtiva do teatro goiano Cleomar Rocha conclua sua análise observando a

[...] existência de dados que podem não refletir a realidade do mercado, motivados pela grande informalidade do setor, mas também por sua característica transversal, podendo ocorrer choques de atividades econômicas (CNAEs) e profissionais (CBOs), com atuação em outros setores, com destaque para esses: trabalhadores de instalações elétricas, nos serviços de higiene e embelezamento, camareiros, roupeiros e afins, caixas e bilheteiros. (Rocha, 2016, p. 16-7)

Se, por um lado, os sistemas de indicadores culturais até então desenvolvidos representam um esforço inegável de sistematização do universo cultural brasileiro, por outro lado, deve-se ter em mente a sua limitação em oferecer um diagnóstico aderente da realidade teatral do país devido, sobretudo, ao baixo nível de institucionalidade das artes cênicas brasileiras. Por exemplo, algumas profissões cruciais ao fazer teatral - como a da figurinista - não figuram nem na Classificação das Atividades Econômicas (voltada às empresas) nem na Classificação Brasileira de Ocupações (focando os indivíduos). Como oferecer um retrato convincente da realidade teatral do país considerando lacunas impossíveis de se ignorar? 
O estudo de Rocha mencionado acima afigura-se como uma tentativa de superar tais obstáculos sob a perspectiva conceitual de uma "cadeia produtiva" adaptada ao caso teatral. Esforços sistêmicos semelhantes já foram realizados por alguns economistas nas demais expressões artístico-culturais, como comprovam estudos sobre as Cadeias Produtivas do Carnaval (Prestes Filho et al., 2009), do Livro (Earp \& Kornis, 2005), das Artes Visuais (Earp \& Kornis, 2010) e da Música (Prestes Filho, 2005). Tais investigações mostram a pujança agregada destas indústrias culturais, havendo, todavia, exclusões consideráveis. Citando apenas um exemplo, no estudo sobre as artes visuais, desconsidera-se alguns nós cruciais do circuito artístico contemporâneo (sejam elas mais ou menos institucionais, como as residências, ou relativas à criação e/ou hibridização de suportes artísticos, considerando a performance art, a land art e a vídeo art). A economia da cadeia produtiva das artes visuais privilegia as entidades mercadológicas e os gêneros artísticos tradicionais que constituem um mercado de arte historicamente instituído.

Se tais pesquisas se demonstram reveladoras quanto aos seus objetos investigados, o mesmo não pode ser dito em relação às artes cênicas. Para explicar a inadequação aqui esboçada, é útil referir-se ao contexto de uso por excelência da noção de "cadeia produtiva", estreitamente associada ao cultivo agroindustrial. Conforme pontua o engenheiro agrônomo Antônio Maria Gomes de Castro, o uso desta expressão ressalta uma visão sistêmica para o setor agrícola compreendido a partir de então enquanto agronegócio ou agrobusiness (Castro, 2001), havendo aí uma superação da dicotomia do setor agrícola versus o setor industrial. ${ }^{8}$ Justamente por isso, encontram-se estudos de cadeia produtiva dos mais diversos, focalizando, em sua maioria, commodities. O cultivo do teatro, diversamente das indústrias culturais, difere em absoluto destas matérias-primas de origem primária, seja pela produção industrial em larga escala, pelo sequenciamento de etapas, pela possibilidade de estocagem ou ainda pelo consumo mundial.

Se o enfoque sistêmico prometido pela "cadeia produtiva" se revela inadequado para o caso teatral, é preciso, pois, buscar outro conceito sem prejuízo da abordagem. Em outras palavras, a necessidade de buscar um sistema para o caso teatral deve permanecer, sem que seja obrigatório o uso exclusivo de uma noção cujo modelo esteja atado ao paradigma industrial. ${ }^{9}$ Mas qual seria este?

A lógica das redes caracteriza fortemente o nosso contexto cultural. De fato, não se concebe hoje formas de sociabilidade que não confiem nas tecnologias de informação enquanto poderosos instrumentos de interação. As redes sociais estabelecem vínculos entre os indivíduos, ultrapassando o ciberespaço e se materializando no mundo real. Não faltam exemplos da imbricação real-virtual, desde os softwares livres, os códigos abertos ou as plataformas open data, passando por aplicativos de compartilhamento de bens e serviços e chegando às disputas políticas.

\footnotetext{
$8 \mathrm{~A}$ passagem a seguir de Castro confirma a pertinência da noção de cadeia produtiva à discussão sobre sistemas: "Os conceitos de agronegócio (ou negócio agrícola), de cadeia produtiva, sistema produtivo constituem aplicações da teoria geral dos sistemas, ou enfoque sistêmico" (Castro, 2001, p. 56).

9 Não se descarta por completo o uso da "cadeia produtiva", pois nada indica que ele não possa ser complementar ao enfoque sistêmico pautado pela rede, descrito a seguir. Loiola (2017) nutre posição semelhante.
} 
Estes e outros casos confirmam a possibilidade de se pensar em uma globalização por meio de sua contraparte, isto é, das dimensões locais descentralizadas de constituição produtiva e social tendo em vista a deterioração dos dispositivos reguladores do Estado-nação. Isto implica em reconhecer as muitas faces do Capitalismo Cognitivo, não devendo ele ser compreendido apenas enquanto sinônimo de uma etapa mais feroz de acumulação do capital cadenciada pela desregionalização global da produção e pelos fluxos vadios do mercado financeiro plasmados em indicadores de desempenho e produtividade. Pois, se há uma potencialidade no Capitalismo Cognitivo, ela está vinculada a uma reavaliação positiva da informalidade, da flexibilidade, do conhecimento e da imaterialidade, cabendo inclusive reconsiderações de modos e sistemas de produção anteriores e paralelos ao paradigma fordista do chão de fábrica. A promessa do pós-fordismo está, portanto, atrelada também a uma reconsideração do pré e do extra-fordismo.

Neste contexto, os modelos de desenvolvimento estão pautados pela coordenação de seus integrantes, havendo aí dois deslocamentos associados: de um lado, a passagem do modelo hierarquizado das políticas públicas para um modelo descentralizado da ação pública; e, de outro lado, a superação da dicotomia global-local tendo em vista o desenvolvimento territorial fundado em relações de proximidade, flexibilidade e reciprocidade não necessariamente mercantis. Assim, no Capitalismo Cognitivo, tem-se tanto um pensamento macroeconômico pautado em valores agregados dissociados de territorialidade quanto as externalidades territoriais resultantes de uma atmosfera criativa compartilhadas por redes específicas (Pecqueur, 2005).

Se o novo paradigma tecnológico associado aos computadores, à microeletrônica e à comunicação digital estimula a proliferação das redes, seria um exagero, contudo, afirmar que as redes surgiram com a internet. Partindo da constatação da onipresença e da onipotência atuais da rede, Musso (2010) desenvolve um percurso histórico desta noção, desde a Antiguidade até mais recentemente, quando ela é alvo tanto de promessas eufóricas da democracia planetária quanto de toda sorte de desconfianças no seio da Sociedade de Controle. Castells (2005), por sua vez, esclarece que as redes são formas de organização social que existem há séculos, apresentando vantagens e obstáculos. Se a flexibilidade e a adaptabilidade são seus principais atributos, a dificuldade de coordenação é seu principal obstáculo, fazendo com que a rede se restringisse ao âmbito privado, enquanto que a centralização e a verticalização estruturavam o mundo produtivo. Com o advento das novas tecnologias, as redes territoriais conseguem superar seus obstáculos históricos, caracterizando também os contextos produtivos: "O que é novo é o facto de [o conhecimento e a informação] serem de base microelectrónica, através de redes tecnológicas que fornecem novas capacidades a uma velha forma de organização social: as redes" (Castells, 2005, p. 17).

O que nos leva a crer que a rede poderia funcionar como o modelo sistêmico para o teatro brasileiro? Em primeiro lugar, deve-se ter mente o fato de a economia, em toda a sua história enquanto disciplina, não ter conseguido descrever apropriadamente os fenômenos culturais, em geral. Nas palavras de Paul Tolila $(2007$, p. 26), 
grande espaço nas ideias e nas preocupações dos economistas clássicos porque a própria estrutura da doutrina econômica, a arquitetura de seus conceitos e seus pressupostos, excluía a cultura do campo da observação útil e legítima em economia.

Mais recentemente, a inadequação do teatro à economia foi atualizada, inaugurando a Economia da Cultura por meio dos estudos de William Baumol e seus pares publicados a partir da década de sessenta. Segundo ele, as artes cênicas - por serem e representarem a imagem arquetípica de um setor estagnante e não-produtivo, visto que caracterizado pelo trabalho intensivo - não seriam viáveis economicamente. Se outros setores - fundamentalmente industriais - experimentam ganhos de produtividade resultantes de inovações tecnológicas, o teatro permanece sendo uma atividade artesanal, sem que atores e criadores possam ser substituídos pela eficiência das máquinas. A impossibilidade de se substituir por completo o homem por dispositivos tecnológicos, aliada à tendência de crescimento dos salários dos criadores de modo proporcional aos profissionais dos setores mais produtivos, faz com que o teatro - uma atividade dependente inteiramente da presença humana sofra fatalmente da "doença dos custos". Eis o dilema econômico das artes cênicas: a prática teatral não sobrevive a (em) uma economia de mercado, a não ser subsidiada. Daí, advém o grave desafio em se falar de um "mercado de teatro": como pode haver um mercado teatral composto por práticas econômicas que geram patologicamente custos, mas não lucro? (Friques, 2016; Friques \& Luque, 2016).

Ora, mas se a economia não é capaz de explicar a persistência do teatro apesar do mercado, tal fato diz tanto dos limites do teatro (na economia de mercado) quanto das restrições da economia (no trato com o teatro). Faz-se necessário, assim, recorrer a outros saberes (sem descartar, evidentemente, a economia). Pois, mesmo que o teatro seja inviável economicamente, não há como negar que as relações criativas e produtivas entre os agentes teatrais estejam permeadas por transações comerciais. Em outras palavras, mesmo que não haja uma economia (no sentido de economy, isto é, enquanto disciplina) do teatro, não se pode negar a existência de uma economia (no sentido de economics, ou seja, enquanto conjunto de práticas) do teatro. Surpreendentemente, muitas das características econômicas encontradas em uma criação teatral - o trabalho como um fim em si mesmo, o processo colaborativo etc. - são também, conforme pontua Herscovici, traços fundamentais das indústrias criativas surgidas nas últimas décadas, organizadas, em sua maioria, em redes (Herscovici, 2010).

Se o teatro é uma exceção à era industrial, ele parece se adequar melhor a uma lógica das redes que inaugura o nosso momento pós-industrial. Abordar o teatro brasileiro enquanto uma "rede de redes" soa promissor devido a algumas características transversais tanto ao teatro brasileiro quanto o modelo topológico das redes. Em primeiro lugar, as redes não são lineares, ao contrário do que supõe a noção de cadeia produtiva. As redes configuram sistemas complexos ${ }^{10}$ que incorporam a própria dinâmica em sua estrutura, dificultando a fixidez e a rigidez permanentes. Uma abordagem histórica e/ou sociológica do teatro brasileiro confirma a ausência de

10 Para Scott Page (2015, p. 12), os "sistemas complexos consistem de atores diversos e que se adaptam, que interagem com seus vizinhos e por conexões de redes". 
perenidade tanto do fenômeno cênico quanto de instituições, companhias, grupos e políticas. Por outro lado, ao longo dos séculos, a história do teatro brasileiro foi escrita através de criações coletivas e processos colaborativos de grupos amadores, companhias profissionais e coletivos de artistas. A rede, portanto, permite abordá-las descartando-se a retórica da falta, de forma a assumir a impermanência em sua própria dinâmica. Em segundo lugar, a rede é um sistema distributivo, com performance policêntrica e flexível, aspectos que estimulam a autonomia, a criatividade e, sobretudo, as interações e a sociabilidade. Sob esta perspectiva, a rede nos permite assumir que o teatro é realizado através de performances e autorias compartilhadas e descentralizadas, com projetos que se formam em espaços determinados e que desaparecem com o tempo. Sendo assim, o caráter intermediário da rede sociotécnica não se refere apenas à conexão e à circulação que ela permite entre diversos nós e agentes heterogêneos, mas também às passagens de estados mais ou menos formais, mais ou menos institucionais que tendem a desvanecer com o tempo. Complementarmente, a rede é também uma "tecnologia do espírito", sendo uma imagem poderosa para a criatividade social e também enquanto modo de raciocínio individual. Em suma, o esforço de sistematização do teatro brasileiro só ganharia caso o retirássemos da sombra econômico-industrial, passando a considera-lo enquanto redes sociotécnicas em constante movimento, buscando não necessariamente maiores rendimentos, mas mais criatividade. Pois:

Já que cada um contribui, ou pode contribuir, para a concepção, já que cada um participa, ou pode participar, da adaptação, já que nada é dado na origem, pois de fato não há origem, pois, o sucesso depende das adaptações e das transformações feitas por todos aqueles que se apoderam da inovação, este modelo dá a todos os atores espaços de escolhas estratégicas, enquanto que o modelo da difusão, inversamente, negava a existência dessas margens de manobra. (Callon, 2010, p. 72)

É curioso observar que o modelo da rede, apesar de ser extremamente multidisciplinar e ter despertado interesse nas mais diversas áreas, ter encontrado um terreno fértil de discussão e aplicação no âmbito das ciências da comunicação. Esta observação se torna ainda mais pertinente quando se tem mente, no âmbito da presente discussão, a estreita vinculação entre o sistema literário de Antônio Candido e o ato de comunicação, de um lado, e o entusiasmo de Lévi-Strauss com as conquistas científicas da comunicação, de outro. O nosso esforço reflexivo mantém, portanto, o desejo de se pensar histórica e sociologicamente expressões culturais tendo em vista paradigmas desenvolvidos no âmbito das ciências da comunicação, apostando, contudo, em desvios estruturais baseados na ideia de "sistemas complexos". Nesse contexto, o teatro brasileiro deixa de ser a exceção para configurar um modelo bem-sucedido de redes sociotécnicas pautado por princípios de conexão, heterogeneidade, multiplicidade, descentralização etc. Sintomaticamente, muitos destes princípios foram associados por Deleuze e Guatarri (1995) ao rizoma, noção extremamente difundida entre os teóricos e fazedores de teatro. O desafio agora é pensar tais princípios em um exercício tanto de conceituação do fazer artístico quanto, sobretudo, de modelização e de organização de nosso sistema teatral. 
Eis uma poderosa oportunidade para a organização contemporânea de nosso sistema teatral. Desviando-se de uma noção de sistema moderno posta em funcionamento pelo filtro analítico de um crítico-historiador, o teatro brasileiro pode se fortalecer por meio das novas tecnologias de comunicação e informação, atravessando as medições e mediações econômicas rumo a metodologias qualitativas que descrevam apropriadamente - ou seja, de modo bottom-up e não mais top-down o conjunto de transações, relações e afetos que conectam os artistas, fornecedores, frequentadores e demais atores que participam dos processos criativos e produtivos associados às artes cênicas. Para mapear estas conectividades e proximidades, é necessário realizar etnografias culturais que - à luz do paradigma do Capitalismo Cognitivo e partindo da constatação de que a dimensão econômica não esgota uma abordagem sistêmica da produção teatral - proponha um modelo de mapeamento territorializado e interacional de modo a tornar visíveis as múltiplas transações e relações sociais, criativas, territoriais e produtivas que caracterizam o nosso sistema teatral. Quem sabe então compreenderemos, de modo mais denso e sistemático, que o homo economicus não é necessariamente o homo ludens, constatando por fim a importância de nosso teatro para o desenvolvimento territorial?

\section{Referências}

BRANDÃO, Tania. Ora, direis ouvir estrelas: historiografia e história do teatro brasileiro. In: Sala Preta, ano 1, v. 1, São Paulo, sep. 2001b, p. 199-217.

BRANDÃO, Tania. Teatro brasileiro do século XX: as oscilações vertiginosas. In: Revista do IPHAN, n. 29, Rio de Janeiro, 2001a, p. 301-335.

CABRAL, J. P.; THOMAZ, Omar Ribeiro (2011). Radcliffe-Brown v António Candido: um debate inacabado. Mana 17 (1), 187-204.

CALLON, Michel. Por uma nova abordagem da ciência, da inovação e do Mercado. O papel das redes sociotécnicas. In: PARENTE, André (org.). Tramas da Rede: novas dimensões filosóficas, estéticas e políticas da comunicação. Porto Alegre: Sulina, 2010.

CANDIDO, Antônio. Formação da Literatura Brasileira: momento decisivos. 6. Ed. Belo Horizonte, Editora Itatiaia Ltda., 2000.

CANDIDO, Antônio. Iniciação à Literatura Brasileira. Rio de Janeiro: Ouro sobre Azul, 2004.

CANDIDO, Antônio. O significado de Raízes do Brasil. In: HOLANDA, Sérgio Buarque de. Raízes do Brasil. São Paulo: Companhia das Letras, 2014.

CARREIRA, André. Teatro de grupo: reconstruindo o teatro? D'APesquisa, 2008. Disponível em http://www.ceart.udesc.br/revista_dapesquisa/volume3/numero1/ 
cenicas/prof_andre.pdf, acessado em setembro de 2017.

CASTELLS, Manuel. A era da informação: economia, sociedade e cultura. Vol. 3. Fim de Milênio. Tradução de Klauss Brandini Gerhardt e Roneide Venancio Majer. 6a reimpressão. São Paulo: Paz e Terra, 2012.

CASTELLS, Manuel. CARDOSO, Gustavo (Org.) A Sociedade em Rede Do Conhecimento à Acção Política. Lisboa: Imprensa Nacional, Casa da Moeda, 2005.

CASTRO, Antônio Maria Gomes de. Prospecção de cadeias produtivas e gestão da informação. Revista Transinformação, v. 13, n², p. 55-72, julho/dezembro, 2001.

COCCO, Giuseppe. A cidade policêntrica e o trabalho da multidão. Lugar Comum (UFRJ), Rio de Janeiro, v. 1, n.9-10, p. 61-90, 2000.

DELEUZE, Gilles. GUATARRI, Félix. Mil platôs: capitalismo e esquizofrenia, vol. 1. São Paulo: Ed. 34, 1995.

EARP, Fabio Sá; KORNIS, George. A economia da cadeia produtiva do livro. Rio de Janeiro: BNDES, 2005.

EARP, Fábio. KORNIS, George. Projeto de Pesquisa: Estudo da Cadeia Produtiva das Artes Visuais. Rio de Janeiro: UFRJ, 2010.

FARIA, J. R. O teatro na estante. São Paulo: Ateliê Editorial, 1998.

FLUSSER, Vilém. O mundo codificado: por uma filosofia do design e da comunicação. São Paulo: Cosac Naify, 2007.

FRIQUES, Manoel Silvestre. LUQUE, Brayan. Economics of Brazilian performing arts: financing and employment. In: Brazilian Journal of Science and Technology, v. 3, n.1, 2016.

FRIQUES, Manoel Silvestre. Edital é pouco, meu prêmio primeiro: uma análise material do "mercado" teatral brasileiro. In: Sala Preta, v. 16, n.1, 2016.

FRIQUES, Manoel Silvestre. Não sobre o amor: produção de presença e novas mídias na arte contemporânea. In: O Percevejo, v.3, n.1, 2011.

FRIQUES, Manoel Silvestre. Trompe-l oeils disjuntivos de Mallory Catlett - Crítica da peça This Was The End da companhia Restless NYC. In: Questão de Crítica, v. 7, 2014.

GOMES, P. E. S. Cinema: Trajetória no Subdesenvolvimento. São Paulo: Paz e Terra, 1996. 
GUINSBURG, J. \& PATRIOTA, R. Teatro Brasileiro: ideias de uma história. São Paulo: perspectiva, 2012.

HALL, Stuart. Da diáspora: identidade e mediações culturais. Belo Horizonte: Editora UFMG, 2013.

HERSCOVICl, A. Artes Cênicas: análise econômica, modalidades de financiamento e novas perspectivas na era da economia digital. In: BOLAÑO, C. et al. (Org.). Economia da arte e da cultura. São Paulo: Itaú Cultural; São Leopoldo: Cepos/Unisinos; Porto Alegre: PPGCOM/UFRGS; São Cristóvão: Obscom/UFS, 2010. p. 119-136.

LÉVI-STRAUSS, Claude. Antropologia Estrutural I. São Paulo: Cosac \& Naify, 2012.

LÉVI-STRAUSS, Claude. Tristes Trópicos. São Paulo: Cia das Letras, 1996.

LIMA, L. C. A concepção da historia literária na Formação. In: LIMA, L. C. Pensando nos trópicos. Rio de Janeiro: Rocco, 1991. p.149-166.

LINS, Cristina Pereira de Carvalho. Levantamento da ação institucional entre o MinC e o IBGE: desde as gestões Gil/Juca. Políticas Culturais em Revista, 2(8), p. 1-27, 2015.

LINS, Cristina Pereira de Carvalho. Sistema de Informações e Indicadores Culturais. In: Anais do III ENECULT - Encontro de Estudos Multidisciplinares em Cultura, maio de 2007, Faculdade de Comunicação/UFBA, Salvador-Bahia-Brasil.

LINS, Cristina Pereira de Carvalho. Sistema de Informações e Indicadores Culturais 2003-2005. In: Anais do IV ENECULT - Encontro de Estudos Multidisciplinares em Cultura, maio de 2008, Faculdade de Comunicação/UFBA, Salvador-Bahia-Brasil.

LOIOLA, Elisabeth. Proposição de Método de Mapeamento de Cadeias Produtivas de Setores das Artes. In: VALIATI, Leandro; FIALHO, Ana Letícia. (Org.) Atlas Econômico da Cultura Brasileira: Metodologia I. Porto Alegre: Editora da UFRGS/CEGOV, 2017.

MERLEAU-PONTY, Maurice. O Olho e O espírito. São Paulo: Cosac Naify Portátil, 2013.

MUSSO, Pierre. A filosofia da Rede. In: PARENTE, André (org.). Tramas da Rede: novas dimensões filosóficas, estéticas e políticas da comunicação. Porto Alegre: Sulina, 2010.

NOSELLA, B. L. D. "O nascimento do Teatro Brasileiro Moderno: modernismo e nacionalismo no pensamento de Décio de Almeida Prado" In: Anais do VI Congresso de Pesquisa e Pós-Graduação em Artes Cênicas, 2010.

PAGE, Scott. Prefácio. FURTADO, Bernardo A.; SAKOWSKI, Patrícia A. M.; TÓVOLLI, 
Marina H. (ed.) Modelagem de sistemas complexos para políticas públicas. Brasília: IPEA, 2015.

PECQUEUR, Bernard. O desenvolvimento territorial: uma nova abordagem dos processos de desenvolvimento para as economias do sul. Raízes, Campina Grande, Vol. 24, nos 01 e 02, p. 10-22, jan./dez. 2005.

PRADO, D. A. Teatro de Anchieta a Alencar. São Paulo: Editora Perspectiva, 1993.

PRESTES FILHO, Luiz Carlos. Cadeia Produtiva da Economia da Música. Rio de Janeiro: E-papers, 2005.

PRESTES FILHO, Luiz Carlos. Cadeia Produtiva da Economia do Carnaval. Rio de Janeiro: E-papers, 2009.

RADCLIFFE-BROWN, A. R. Estrutura e Função em sociedade primitiva. Rio de Janeiro: Vozes, 1973.

REY, Diana Marcela. Sistemas de informação cultural: aprendizagens e desafios na América Latina. In: Políticas Culturais em Revista, 2(8), p. 173-187, 2015.

ROCHA, Cleomar (org.). Teatro em Goiás. Goiânia: Gráfica da UFG, 2016.

SCHWARCZ, Roberto. Antônio Candido. Blog da editora Boitempo, maio 2017. Disponível em: https://blogdaboitempo.com.br/2017/05/12/antonio-candido-por-roberto-schwarz/. Acesso em: 11 set. 2017.

SUSSEKIND, Flora. Que eficácia pode ter? Adaptabilidade e resistência. In: SUSSEKIND, Flora. DIAS, Tania. PEDROSA, Celia (org.) Crítica e Valor: uma homenagem a Silviano Santiago. Rio de Janeiro: Fundação Casa de Rui Barbosa, 2014.

TOLILA, Paul. Cultura e economia: problemas, hipóteses, pistas. São Paulo: Iluminuras: Itaú Cultural, 2007.

TORRES NETO, Walter Lima. Cultura teatral: ensaios sobre a prática do teatro. Trabalho apresentado como requisito para progressão funcional da classe Associado para classe Titular. Universidade Federal do Paraná, 2015.

Recebido em: 14/10/2017

Aprovado em: 20/06/2018 